\title{
Rescuing the ghost from the machine: towards responsive education and beyond explanatory machinery systems
}

\author{
Carlos Sousa Reis ${ }^{1}$, Maria Formosinho ${ }^{2}$, Paulo Jesus ${ }^{3}$ \\ ${ }^{*}$ Coimbra University (Portugal) \\ Centro de Estudos Interdisciplinares do Século XX da Universidade de Coimbra (CEIS20) \\ Faculdade de Psicologia e de Ciências da Educação, Rua do Colégio Novo, 3000-115 Coimbra, Portugal \\ Tel.: +351 239851 450, Fax: +351239851462, csreis@uc.pt \\ ${ }^{*}$ Coimbra University (Portugal) \\ Centro de Estudos Interdisciplinares do Século XX da Universidade de Coimbra (CEIS20) \\ Rua Filipe Simões, no 33, 3000-186 Coimbra, Portugal, msimoes@upt.pt \\ ${ }^{* * *}$ Philosophy Center of Lisbon University \\ and Portucalense University (Portugal) \\ Rua Dr. António Bernardino de Almeida, no 541, 4200-072 Porto, Portugal, pauloj@upt.pt
}

\begin{abstract}
The significance of the "Bologna Turn" in European Higher Education, which supposedly refocused the process of teaching and learning and was expected to bring about a pedagogical reform, is discussed mainly by clarifying why it has not in fact realized the expected advances on performativity and standardization. We show how the "Bologna Process" falls into the mechanistic paradigm that Rancière (1987) acutely criticized and through which the educational intervening subjects are reduced to a functional dimension. We draw on Rancière's criticism to make clear the dynamics of the "deranging machine", while we call for Buber's "pedagogy of encounter" as having the potential for opening a new space to escape from the current situation by a "pedagogy of an inspiring way of speaking", as this may act as adequate conveyer for accomplishing the desired meaningful encounters. These issues lead us to consider why and how education requires a special "pedagogical tact": the tact for understanding that education is an antinomical process that flows from, through and towards a meaningful dialogue, so that one can recognize that autonomy is constructed in relation to dependency, freedom in relation to compliance and care in relation to some amount of constraint.
\end{abstract}

Keywords: Bologna Process, Higher Education., Performativity, Pedagogy of Encounter, Dialogism

\section{The Land Of Milk And Honey: An Announced Pedagogical Revolution}

These times are fit for improving us only backwards, by disagreement more than by agreement, by difference more than by similarity. (Montaigne, 1595/1958, p. 703)

The so called "Bologna Process" (BP), intended to develop an integrated European higher education area, explicitly refocused teaching and learning in students' individual work and in student-centred methodologies. However, the apparent mismatches between effectively developed intentions and practices have lead many participants to suspect that, either there were some planning equivoques regarding the BP or worse, the stated purposes could in fact serve less clear options about what was really intended.

In order to critically clarify the above mentioned issue, we must start by considering the promised pedagogical reform on its own terms. Later on we will attempt to present a coherent proposal to the announced "pedagogical revolution", at least with its stated intentions, which may be far from the promoted political measures and the practices really encouraged.

In 2007, the London Communiqué, undersigned by the Ministers responsible for Higher Education of the countries participating in the Bologna Process, noticed that there was an increasing awareness about the need for moving towards student-centred learning and away from a teacher driven provision. Two years later, the Leuven Communiqué (2009) stated that to face globalization and accelerated technological developments student-centred learning and mobility are crucial issues regarding the developing of competencies needed in a changing labour market and societies requiring active and responsible citizens. Moreover, the referred Communiqué explicitly reasserts that student-centred learning requires empowering individual learners, new approaches to teaching and learning, effective support and guidance structures and a curriculum focused more clearly on the learner in all three cycles. Curricular reform 
should thus be an on-going process leading to high quality, flexible and more individually tailored education paths.

The same issue was raised a year later in the Budapest-Vienna Declaration (2010), where the Ministers called upon all actors involved to facilitate an inspiring working and learning environment and to foster student-centred learning as a way of empowering the learner in all forms of education, thereby providing the best solution for sustainable and flexible learning paths.

Insisting on the same direction, the Bucharest Communiqué (2012) came to reiterate the Ministers' commitment to promote student-centred learning in higher education, characterized by innovative methods of teaching that involve students as active participants in their own learning. The Communiqué also presents the Ministers' commitment to facilitate - together with institutions, students and staff - a supportive and inspiring working and learning environment (these words are to be marked as they will become useful later on), along with their determination to establish conditions that foster student-centred learning, innovative teaching methods and a supportive and inspiring working and learning environment.

Finally, very close to us, a report from the High Level Group on the Modernisation of Higher Education (2013), titled Improving the quality of teaching and learning in Europe's higher education institutions, came to stress the need for making available pedagogical training for higher education teachers. If such a disposition can be seen as the correspondent's concerns regarding teachers' pedagogical empowerment in order to ensure that innovative and student-centred learning processes actually came to be delivered by teachers, the least one can say is that the BP suffers from an inversion of priorities. Until 2012, the process simply relied on formal calls for pedagogical transformation, while mainly addressing other core issues that have led the agenda since the Bologna Declaration in 1999: 1) mobility of students, teachers and researchers; 2) easily readable and comparable degrees; 3) a system of credits; 4) the adoption of a European standard system for quality assurance.

The real issue here is that such a lag -between the formal call and the agenda really promoted-, seems to uncover the true motivation behind the Bologna Process: a bureaucratic standardization design to align higher education with "managerialistic" and economistic purposes. To understand the real dynamics of this process, we must get back to the BP's initial motivation of tackling the "American research universities" challenge of supplying globalized markets demands, which means that European Higher Education came to address the Globalization Age within the frame of a neoliberal ideology (Cachapuz, 2009). Following the corporatist medieval universitas giving way to the Enlightenment's institution devoted to "universality", it is now time for the Corporate University to rise, on the wings of efficacy and efficiency, over the former now supposedly anachronistic conceptions.

Another clue for getting to the BP's underlying motivations pertains to its development. Although the 1988 precursor, Magna Charta Universitatum was undersigned by Rectors, the following declarations and communiqués came to be undersigned by all Education Ministers, a fact that indicates the top-down model applied to the initiative. It should be noted that the BP has been, above all, focused in the Higher Education Institutions' (HEIs) systems convergence, something that should not be confused with the uniformity of such systems. As Cachapuz (2009) stresses, the Bologna Declaration is not a treaty, undersigned by countries obliged to transpose it to a juridical stance; it cannot be imposed, but should instead be constructed. Such construction is the responsibility of HEIs, although it is common to see that the governments of participant countries take the initiative of leading the process themselves. Furthermore, one should bear in mind that the BP seems to have forgotten the crucial issue of teacher education required for facing the new pedagogical framework. It is an explicitly recognized fact that to date, it has failed to address the substantive pedagogical changes regarding the required so-called student-centred teaching and learning methodologies.

On the one hand, it is now clear that the new pedagogical paradigm should be student-centred and not focused on subject structure or the teacher, thus breaking with the magisterial and transmissive tradition and thereby addressing new interdisciplinary curricular development that addresses student needs by applying innovative methodologies and by being open to the virtualization of the education process. However, the truth is that the implementation of these factors has not yet been achieved. Particularly, teachers' pedagogical training and the deployment of an academic culture congruent with the BPs' aims has had very late acknowledgement. Not only are we not working toward settlement of a new academic culture attuned to active learning methodologies, but we are relying on doubtful student autonomy and fetishist virtual didactic models that are laying siege to the traditional Socratic pedagogical approaches (Díaz, 2010, 2012c). This means the BP is not fostering the conditions for creating "a supportive and inspiring working and learning environment" (Bucharest Communiqué, 2012), or if it is, such concerns are only to be addressed after the "managerialistic" agenda. 
The BP has nonetheless brought together European HEIs regarding some formal issues, such as degrees comparability and recognition, which induced a study cycles shrinkage that many interpret as having been driven by economic motivation. Additionally, the student-centred focus was also used to increase teachers' workloads, with no corresponding development of support conditions. If a new academic environment has settled, it is a bureaucratic, Tayloristic and a controlled one, underpinned by a reductive conception of education quality (Días, 2012a; 2012b). In this new environment, humanities have suffered a strong suppression, along with all those "useless" treasures that humans long for. Hence we are losing space for developing the magnificent human qualities that Morin (2003) described as the flowers of complexity: conscientiousness, the spirit and the soul.

More than an educationally stimulating environment, the BP has been assembling a huge machine refractory to spirituality, which appears to be unabsorbable by mainstream instrumental rationality and its maniacal "performative" approach. This has led us to wanting to contribute to the required new pedagogical environment, which is still lacking within the Bologna Process.

The BP's apparently paidocentric revolution was supposedly aimed at promoting an alternative to a somehow obsolete transmissive machinery in order to replace the dominant magisterial tradition with a student-centred approach. Instead, the BP is now very much falling into the explanation machine paradigm that Rancière (1987) has acutely criticized and through which the educational intervening subjects are reduced to a functional dimension. Anything beyond this dimension is obliterated; thus, spirit can only appear as a void spectrum, ignored by the machine that at the same time reacts ambiguously, as if haunted by any strange nature. We can find here a homology with the Cartesian dualistic relationship between body and soul - res extensa and res cogitans - in which spirit appears as something that does not belong to the bodily machine, for they entertain a merely transitory relationship, given their absolutely distinctive type of res, i.e., their ontological distinctiveness (Koestler, 1967). In fact, as Bates (2014) has shown, such an instrumental approach currently embodies the Strategic ideology -that was originated in business management theory and practice-, conceptualized within the Cartesian paradigm of rationality, order and logic, to which a "subject-object dualism creates a distinction between the detached, knowing subject and human or other resources to be calculated, manipulated and deployed for the aims of strategy" (Bates, 2014, p. 354). Thus an encounter with others as existential subjects is never possible: within the Cartesian world, the others -whether we refer to objects or human beings- always appear as objects to be measured, manipulated, used or improved. For the Strategy ideology, that focus on a calculative reasoning in search of efficiency-efficacy, through matching means to predetermined ends, we only have resources' manipulation, where existences -spirits as ends in themselves, as Kant (2005) would say- can never appear as such. As neither the axiological and teleological issues can be really taken in consideration, while a reflexion on the deeper meaning of the relational issues of education process would have space to be undertaken. Everything out of the manipulative approach of measurable entities and processes are bound to disregard, trivialization and obliteration: they become as ghosts within a machine.

One should therefore ask whether -within the framework of the BP's pedagogical focus, as it has been developed so far-, it is possible to succeed freeing existences (the minds or thinking ghosts) from the machine or whether -in case the machine opens up to accept existences-, one may at least help the machine acknowledge their peculiar nature. Such an operation can only be attained if the machine opens itself to this subtle kind of nature and welcomes such fundamental difference into its realm, thereby overcoming substantial dualism. Only then will these learning spirits stop wandering the shadowy corridors of the machine -haunting it with their mere existence of substantially different realities-, thereby finally being rescued from a life of alienation. To do this, we need a new kind of university, a new institution that must be animated by a supportive and inspiring working and learning environment.

Ultimately, such an issue puts forward the problem of the inclusion of differences, that is, the inclusion of the difference of conditions that a subject has the potential for embodying. With regard to the subject (teacher/student), the machine commonly does not go beyond the recognition of an agent (a machine part), or at best, an actor's role (an operator of machines); it never acknowledges the possibility of an author of meanings (Pourtois \& Desmet, 1997). The machine only accepts, at best, an adaptation that forces the subject into the operative context, where he/she becomes a functionary, i.e., he/she is converted into nothing more than a gear wheel in the system. It is this core tendency that destroys any space for the inclusion of differences such as interests, motivations, desires, skills, rhythms and dissident speeches, among other things. However, it must be emphasized that, regardless of management options, education should address a multidimensional purpose of qualification, socialization and subjectification a domain that "has to do with the way in which children and young people come to exist as subjects of initiative and responsibility rather than as objects of the actions of others" (Biesta, 2015, p. 77). Meaning this that education ought to address the empowerment and emancipation of living minds. 
However, there are now many reasons to believe that the Bologna Process does not represent a methodological turn for overcoming the mechanist paradigm; at the very least, it still lacks the essential conditions for doing so. The aftermath of its "great expectations" is now perceived as pedagogical disappointment, a shallow efficiency assessment, hollow standardization, increasing bureaucracy and above all, funding cuts. That is why we must look for a way to surpass its intrinsic obsession with "performativity". This means we have to discover a path that opens up the possibility of recognition of the spirit by the machine. Could this be one of those "happy failures" Melville (2009) so well describes, by which we learn to be more concerned with the invention of happiness than anything else?

Our effort will now be readdressed to find a pedagogical framework focused on students' activity that the BP claimed for but did not prioritize, indicated but did not promote. Such an exploration may bring forth some clarification on the adequate processes to serve the declared intentions. Hence, following Biesta's (2015) critical approach, we will not draw on learning in an abstract sense, presupposing that the point of education is simply that students learn, thus forgetting that, more complexly, they should learn something, for a reason and from someone. Which means education needs to engage with questions of content, purpose and relationships. Right now we will focus in the dimension that refers to education's impact on the students as persons, i.e., pertaining to the domain of subjectification (Biesta, 2015), in which the forms of relationship and the allowed roles are crucial. Although the above referred three domains of purpose cannot, and must not, really be separated, as one-sided conceptions can damage one or more of the other domains, we have a good reason to focus on the later: "the current emphasis on achievement in the domain of qualification where excessive pressure on students (and teachers, for that matter) to perform in that domain (and within that domain in a very small number of subjects) is beginning to have a negative impact in the domain of subjectification" (Biesta, 2015, p. 78). Hence to put some weight on the most neglected plate of the balance seems recommended.

\section{Taking Education Out Of The Explanatory Machinery System}

For rescuing the ghost from the machine, our first challenge is to take it out of the explanation machinery system deployed by the current performativity framework, which the BP helped to install, even when stating very good intentions. According to the provocative educational views of Jacques Rancière (1987), true empowering education is that which succeeds in freeing the spirits from the institutional circuits of the "explanatory machine", the regime of explanations and re-explanations that continuously confirms ignorance and reinforces the assumption of cognitive inequality.

From the above mentioned approach follows that education does not imply a master that orally conveys knowledge, thereby leading the spirits through a progressive path of ascending from simple to complex elements, while avoiding errors and detours so that the appropriation of knowledge advances smoothly and the formation of intelligence and taste may be fully accomplished. Instead, one must aim at reversing the working logic of the "explanatory system", the foundation of which lies in the constitution of inability, conceived from the standpoint of an educational ideology that establishes a divide between the savant and ignorant people, i.e., higher and lower intelligences. If one adopts such an assumption, then one accepts that the master is entitled to decide the absolute departure point from which he alone defines what must be learnt and supplies the criteria to assess the progress of learning and understanding. However, the principle of explanation becomes a principle of spiritual and cognitive destruction: the imperative of explaining and understanding is the origin of all evil - nor does Rousseau's pedagogical cunning of careful presentation of obstacles to be surpassed by the autonomous learning mind escape this radical criticism. The more the master is a savant available for becoming, in good faith, a professional of explanation, the more destructive his/her actions will be.

On the contrary, if we let both characters, intervening in the educational process, face an unknown book, it establishes equality between those who learn by themselves and those who ignore what they teach; without any intermediary explanatory intelligence, the pupil only needs natural intelligence to understand what he wants to understand. All he/she has to do consist of producing, by themselves, a sequence of learning operations: they must observe, rehearse, store, link, prove, correct and even guess. On his side, the ignorant master sets a relationship between free wills, guiding the will of the pupils so that they decide freely to learn and by obeying no one but themselves, reaches intellectual emancipation or cognitive empowerment.

We thus see that within the framework of such a relationship, roles are transformed. The function of the master transmutes into a kind of care that requests focused attention and the stimulation of intelligence's expression. That is why the master poses questions. He must ask in order to be instructed: he relates to the pupil as an equal man, not as a savant, because he acknowledges his ignorance. He does not validate 
ignorance but fosters research and focused attention. Such a process centres on self-directed attention instead of promoting a science that emphasizes the other's inability. In so doing, intelligence focuses on itself to examine what it sees, what it considers to have seen; therefore, it requires first and foremost unconditioned attention to cognitive actions themselves. To such an extent, the pupil will learn without external explanations, just because he wants to, because he has accepted the essential tension created by his own desire or will to understand and because he has allowed the difficulties of his existential situation to provide him with learning goals. He must trust the efficacy of his own cognitive abilities and the motivational strength of his own commitment to develop them, which lays the foundations of human dignity.

In this new context, there will be no fundamental differences between learners' cognitive abilities, whether memory, understanding or judgment. The crucial element would reside in the dynamics of attention focused on meaningful objects, attention that constitutes intelligence itself, relying on the energy of free will that animates it. Any intellectual difference will essentially be derived from the differential use of attentional resources. The quality of learning and of cognitive style will increase depending on their linkage to one's uneasiness and one's sensitivity to the surrounding circumstances and challenges. It hence follows that learning stems from individual motivations and needs, for otherwise attention remains inert. The differences observed in the outcomes proceed from attentional and motivational differences rather than from cognitive differences. The spirit fails and error emerges only when intelligence is affected by a certain kind or degree of distraction. Without focused attention, intelligence is paralyzed by passivity, contempt towards personal achievements is fostered and lack of audacity to embrace creative cognition spreads along with a submissive way of thinking. Erratic or regressive movements by one's free will produce fundamental distraction, which blocks the search efforts feeding the learning process. The lack of attention signals an absence, a perversion or betrayal of one's personal will and thereby amounts to a self-infidelity or lying to oneself. For self-fidelity implies self-centring, which constitutes the very principle of veracity. Depending on the movements of the will that determine the intensity and direction of one's attention, meaningful connections are formed or, alternatively, vanish.

Such an educational perspective seems to anticipate an existentialist approach, as advocated for instance by Karl Jaspers, for whom the essential character of education aims at accomplishing the transformational encounter between a person and their own being or their own selfhood (Neves, 2004). The educator facilitates the access of such personalizing self-focus, in which the educand becomes autonomous and gains awareness of the determining force of "limiting situations" about which there is neither ultimate truth nor valid explanation. In this respect, educator and educand share the same existential condition and the same ground of experience. Indeed, when referring to the anthropological invariants, educator and educand appear on the same footing and establish a horizontal relationship: they are fellows on a joint journey at the existential level. For this reason, a return to the Socratic "Paideia" may be justified in some circumstances, given that it re-enacts the educational relationship in which the master must present himself as ignorant. For, regarding the enigma of existence or the inexhaustible and multifarious substance of truth, educator and educand share the same place in being: both are in search of meaning and truth, and neither may ever claim to have reached a final response. Thus, the educator is not in the position of explaining the unexplainable and given that he/she is as ignorant as the educand, his/her role consists of inviting the educand to join the venture of searching for truth and questioning the answers in a personal and free manner, without accepting the mediation of any so-called authority.

As existential pedagogy would later also maintain the principal resource of a form of that relies in truthful communication through which truthful existences, rooted in common human intelligences can meet, affirm and recognize each other, so that they apply themselves jointly to the ungraspable centre of truth, sharing their meaningful experiences of searching for truth without ever claiming to possess it. The aim of such an education would be to promote the engagement of free spirits in the asymptotic search for truth, thereby fostering the formation of ideas, opinions and joint intellectual ventures, being thus enriched by the non-coincidence of intelligences.

Such a scope appears to hold the following Montaigne's belief (1958/1595, p. 705): "we are born to inquire after truth." Yet at the same time, one must acknowledge that what is said of truth, whenever truthful words and attentive intuitions are animated by a powerful will to understand, allows one solely to attempt at translating truth (and "guessing" truth as it were) into the language and communicational movements of our existences. Rancière embraces the same standpoint when he states: "Thought does not say itself in truth, it expresses itself in truthfulness" (1987, p. 106). Indeed, for Rancière the "principle of truthfulness or veracity" that derives from the impossibility of self-ignorance lies "at the heart of the experience of emancipation" and constitutes the "moral foundation of the power of knowledge" (Rancière, 1987, p. 98). 
Such an educational order, deeply embedded in the will to understand and to be understood, immediately opens up a passage to a "poietic" space, where existential subjectivities jointly engage in the infinite communicational process of expressing, guessing, translating and mutually rectifying truth, whose absolute possession is impossible. It amounts to maintaining, in Rancière's words, that "in the act of speech (parole), man does not convey knowledge, but he poetizes, translates and invites others to do the same" (1987, p. 110). In this respect, one must recognize that such a dialogic vein, which underscores the value of the joint venture of searching as the essence of the common human learning experience, points to a deeply educational attitude. As proposed by Orbe, Bondía \& Sangrá (2006, p. 241), education supposes an "experience of openness", a "poetic and political incision", which introduces novelty from the perspective of a free relationship with the world. In this relationship, we construct ourselves as persons, because "poetics in education is the plot, the story and the narrative that help us invent ourselves" (Orbe, Bondía \& Sangrá, 2006, p. 241).

Education, as conceived in the above mentioned approach, refuses any conciliation with the dictates of science and progressive improvement based on inequality; that is to say, the pedagogy institutionalized by the schooling explanatory machine seems to serve only to infantilize and diminish one's persona and mental activity. In addition, it also denies the principle of a confined, orthodox, pre-understanding, which imposes a rigid educational path to be followed by the pupil. In the realm of a "poietic" space, which should be opened up and enlarged, education must abandon the willing "to lead the educand's attention towards a correct direction, defined in advance, and convert itself into a process of shared attention" (Orbe, Bondía \& Sangrá, 2006, p. 241-242). In so doing, one witnesses the meaningful and liberating emergence of an individual voice. Such an experience may not serve specializations, as Rancière (1987) remarks, but multiplies the power of intelligence; it does not form savants, but raises awareness of one's own intellectual powers.

Regarding the current deployment of the efficacy-efficiency paradigm, installed in higher education, we want now to claim that the dialogic educational insight should be, at least, complementary to others, namely instruction. In the next section, we will venture a way that seems to be congruent with the purposes of a process able to put the learner at the centre of the educational dynamics.

\section{Education As Encounter And Responsive Practice}

Rancière's criticism allowed us to recognize the dynamics of the "deranging machine", now, as we'll see, "pedagogy of encounter" may open a new space to escape from it and, on its side, "pedagogy of an inspiring way of speaking" can offer the adequate conveyer to accomplish these meaningful encounters. If the realm of encounter provides a relational space able to encompass the triple dialectics of the agent/actor/author, in which the roles of actor and author are fully integrated, stimulating the flourishing of the subjective, creative, dimension of the person, that is, of the mind that inhabits the machine and rightfully exercises its proper condition, then one must found the discursive mode that can develop creativity and celebrate the valuable presence of alterity. Therefore, in order to escape the machine's short circuit, one might refer to Buber's pedagogy of encounter (McHenry, 1997) and attempt to accomplish the reincorporation of the subject in all its dimensions, following a kind of education that can and should be developed through an inspiring way of speaking, as proposed by Vansieleghem \& Masschelein (2012). By understanding education as an invitation to speak, one invites those involved in pedagogical relationships to engage in an inspired and an inspiring way of speaking that specifically requires and affirms their full and personal presence.

Underlying such an approach, one finds the assumption that "in the beginning it is relation" (Buber, 2010, p. 18), meaning that humankind's primordial attitude is being-between and being-with, translated into an existential and discursive experience deprived of transitive verbs. Being-between means a dialogical position, in which personhood emerges as an invitation to speak and speech invites embracing a relational mode of being. This dialogue differs sharply from the sort of communication in which there is exchange of information, explanation and demonstration, production of judgments and reasoning and arguments that pose and elucidate questions located in the broad logical flow of discussion, debate or negotiation, in accordance with technically controllable processes. Selfhood and alterity, "I" and "Thou", are co-constructed in and by dialogical movement, for dialogue liberates a kind of speech that is "an abandoning or exposing of oneself" and therefore "less an activity than a passivity or passion, through which one becomes present in the present, a being with, which is also a kind of invitation" that always puts oneself at stake (Vansieleghem \& Masschelein, 2012, p. 3). This is precisely an invitation to welcome one another's presence, the movement of the primordial word I-Thou; an inspirational speaking that requires inspiration in order to take place and make present the missing and living alterity of the other. 
Vansieleghem and Masschelein (2012, p. 87) distinguish this type of dialogue from common, prosaic, dialogues: "If it is common in academic parlance to speak of the 'exposition' of an argument or of someone's views, the speaking we have in mind is an 'ex-position' - that is, a speaking that puts one out of position. And we can recall here the proximity of this thought to that of exposure and even educere, all involving a movement outside or beyond oneself." This constitutes a sui generis form of dialogue that "exposes an invitation to speak, it being understood that an invitation to speak requires speaking as invitation: it requires the opening of a new dimension of thinking and acting" (Vansieleghem \& Masschelein, 2012, p. 87). In such a way of speaking, the interlocutors expose themselves to whatever may happen and to being present; thus, the interlocutors become mutually present, not to claim the truth or validity of anything, but rather to affectively experience the process of close presence, of being-with, which entails the availability of engaging one's own subjectivity and liberate it so that one is liberated from oneself and open to difference, to feeling and thinking otherwise. Here one is invited to live the passion of recognition and acceptance of whatever, whoever, is present, which goes far beyond any reflection on the chaining of arguments that compose sound reasoning.

Within an encounter, which the inspired and inspiring speaking invites to make happen, the words with their pre-established usages and meanings appear to be unable to be spoken, for the presence comes to speech with radical novelty. New words must be commonly coined to make the presence speak its own language. The free passion of being affected by alterity does not deploy any exercise of predications or judgments. Instead, it is the openness to being-present-with; it invites the emergence of presence and at the same time is presence revealing itself and giving presence to the other so that oneself and the other may emerge jointly from the mere world of things, the world of the explainable causal chain of beings, a world void of novel presences but full of past determining forces. The world of meaningful presence and life is both the condition and the creation of encounters. Insofar as human beings refer themselves to the world of things and confine themselves within its boundaries, they only inhabit the past and their moment is deprived of all present content. However, whenever one utters the word 'You', one is no longer relating to things determined by their past, but to creative presences; for you is always affecting and being affected by 'me', and thereby creates a world of relationships in which true speaking flows within the context of recognition and acceptance that exposes the interlocutors and puts them "out of position", out of the roles and functions they represent, but mutilate their presence and prevent them from being or becoming all they can be and become.

According to this view, our existences are not conceivable as simply 'givens'; instead, they must be assumed rather as tasks one is responsible for, that one must take care of. In a radical sense, selfhood is essentially the awareness of the permanent urgency of 'care', that is to say, care or concern for oneself, an idea that culturally takes root in the ancient cura sui -poignantly analysed by Foucault $(1984,2001)$-, which has resurfaced with Heidegger's (1927/2008) Sorge located at the heart of Dasein. The speaking that addresses existence must welcome its ever surprising and creative movement, which invites a new language to take place, the language inspired by presence and inspiring that same presence, a revealing and liberating way of speaking-with that reinvents language itself and through which the novelty of meaning allows the expressive emergence of authenticity. One of the major paradoxes of the Bologna Process lies in its emphasizing the student's autonomy while implementing standardized managerial procedures to such an extent that cura sui becomes a post-humanist manifestation of a governmentalized organization, an epiphenomenon of a political technology to produce and reproduce a historically determined pattern of competent citizenship (Fejes, 2008a, 2008b; Foucault, 2001).

Instead of a standardized set of performances for building and governing subjectivities, education is a unique dialogical event which, once addressed to free minds, will flow far beyond "governmentality", and will be nourished by this inspired and inspiring way of speaking that invites and expands itself, producing communal and novel meaning that stems from the authenticity of co-existence and co-care in an open, unbounded, presence. Such a presence is not the object of explanations and judgments, but appears as a questioning, and for this reason may leave us speechless, mute and attentive to our existence, fascinated by our existence, and open to a new way of speaking; that is, speaking in its novelty, from which the inspired and inspiring speaking emerges. The critical liberation from all pre-conceived frameworks makes available recognition, commitment and acceptance, where the presence revealing itself and its way of speaking becomes an invitation to being. Such an "encounter" does not necessarily need to be translated into speaking; it can be expressed by the qualities of bodily posture and visual contact. Moreover, the encounter may experience difficulty in coming to language and therefore may appear to prefer the silence of listening. Being out of their secure positions, the interlocutors are convoked into an open environment in which they expose themselves. However, one must ask, is this mode of speaking really adequate for the liberation of the spirit from the machine? The answer may be found in a passage by Buber, in which he 
describes the "living speech" that plunges one into "the truth of relation" or which one encounters as being deeper and higher than "the spirit of knowledge and the spirit of art":

Here, the Thou appeared to the man out of deeper mystery, addressed him even out of the darkness, and he responded with his life. Here the word has from time to time become life, and this life is teaching. This life may have fulfilled the law or broken it; both are continually necessary, that spirit may not die on earth. This life is presented, then, to those who come later, to teach them not what is and must be, but how life is lived in the spirit, face to face with the Thou. (Buber, 2010, p. 42)

This approach is all the more relevant and even more human and humanizing when it concerns those voices that are marginal to the dominating system, voices that speak the language of difference and minority. In a line that seems to be congruent with the relational emphasis, one may also refer to Jean-François Lyotard's proposal (Dhillon \& Standish, 2000), according to which one must bear witness of the differences between voices and find adequate languages to express them, suggesting that art and feeling might be the best means for opening up the human enigma between interlocutors. Not only does art seem to be the most adequate means for expressing that which is different, which cannot find any faithful vocabulary to express itself in the dominating language game, but it also through art that one awakens good consciousnesses from their insensibility towards the silenced cry of difference. In this regard, one requires a meticulous and patient work of "just education"; that is, education freed from the confines of performativity and responsive to the expressivity of polyphonic sensibilities.

To our minds and within the dialogical view of educational antinomies (Reis, 2014), the fact of acknowledging that education is accomplished through encounter does not entail the total negligence of instruction. Likewise, being an author cannot annihilate the actor and the agent; formation cannot deny the value of information; self-education cannot oppose hetero-education; development of rationality should not destroy the development of affectivity. However, it is the ability to articulate in renewed configurations those antinomian principles, embedded conflictingly within the educational field and the concrete educational situation that can aptly justify the complex understanding of education as science, technique and art. The educational realm claims art from the highest level of the presence between minds; a kind of art requiring an unconditional acceptance and free gift of oneself through a way of speaking that is inspired by the presence, and which is inspirational to the quality of presence, thus inviting one to the authenticity of being in language. Even if one is chiefly concerned with the logic of explanation and planning, one cannot avoid asking for the quality that sustains this educational mode and which is sensitive to the antinomian nature of the project aiming at being through and for dialogue.

Here, as in many other aspects of education, there is the apparent paradox of accessing something from that which, conceptually, supposes its contrary. Namely, autonomy being constructed from dependency, freedom from respect for the norms, and dialogical attitudes from initial constraint, until the attentive listening to others and acceptance of their legitimacy. Pedagogical tact is, in our view, to know how to combine these apparent antinomies (we should not forget we are in the field of complexity), without thereby having to arrive at some intermediate fixed point, especially because we must interpret at each moment what can foster the learner's personal development. (Asensio, 2004, p. 235)

This would be the case if we really want to get the Bologna Process, currently captured by the "performative" obsession, back on track with its underlying principles.

\section{References}

Asensio, J. M. (2004). Una educación para el diálogo. Barcelona: Paidós.

Bates, A. (2014). (Mis)Understanding Strategy as a 'Spectacular Intervention': A Phenomenological Reflection on the Strategy Orientations Underpinning School Improvement in England. Studies in Philosophy and Education, 33(4), 353-367.

Biesta, G. (2015). What is education for? On good education, teacher judgment and education professionalism. European Journal of Education, 50(1), 75-87.

Buber, M. (2010/1923). I and Thou. Connecticut: Martino Publishing.

Cachapuz, A. F. (2009). A construção do espaço europeu de ensino superior: Um case study da globalização, Revista Espaço Pedagógico, 16(2), 123-134.

Dhillon, P. A., \& Standish, P. (2000). Jean-François Lyotard: Just education in passing. In P. A. Dhillon \& P. Standish (Eds.), Lyotard: Just education (pp. 11-18). London: Routledge.

Díaz, J. M. H. (2010). La universidade de nuestro tiempo y conflicto de racionalidades. Ensino Magazine, XIII, 149.

Díaz, J. M. H. (2012a). Desmantelar la Universidad Pública. Ensino Magazine, XV, 167.

Díaz, J. M. H. (2012b). Universidad sin horizontes. Ensino Magazine, XV, 170.

Díaz, J. M. H. (2012c). Fetichismos en la Universidad. Ensino Magazine, XV, 177. 
European Commission (2013). Improving the quality of teaching and learning in Europe's higher education institutions. Luxembourg: Publications Office of the European Union.

European Higher Education Area Ministers Conference (1999). The Bologna Declaration. Retrieved from http://www.ehea.info/article-details.aspx?ArticleId=43

European Higher Education Area Ministers Conference (2007). London Communique: Towards the European Higher Education Area, responding to challenges in a globalised world. Retrieved from http://www.ehea.info/article-details.aspx?ArticleId=43

European Higher Education Area Ministers Conference (2009). Leuven Communique: The Bologna Process 2020, The European Higher Education Area in the new decade. Retrieved from http://www.ehea.info/article-details.aspx?ArticleId=43

European Higher Education Area Ministers Conference (2010). Budapest-Vienna Declaration on the European Higher Education Arear Retrieved from http://www.ehea.info/article-details.aspx?ArticleId=43

European Higher Education Area Ministers Conference (2012). Bucharest Communique: Making the Most of Our Potential, Consolidating the European Higher Education Area. Retrieved from http://www.ehea.info/article-details.aspx?ArticleId=43

Fejes, A. (2008a). European citizens under construction: The Bologna process analysed from a governmentality perspective. Educational Philosophy and Theory, 40(4), 515-530.

Fejes, A. (2008b). Standardising Europe: The Bologna Process and new modes of governing. Learning and Teaching: The International Journal of Higher Education in the Social Sciences, 1(2), 25-49.

Foucault, M. (1984). Histoire de la sexualité III: Le souci de soi. Paris: Gallimard.

Foucault, M. (2001). L'herméneutique du sujet: Cours au Collège de France 1981-1982. Paris: Gallimard/Seuil.

Heidegger, M. (1927/2008). Being and time (transl. J. Macquarrie \& E. Robinson). New York: Harper \& Row.

Kant, I. (2005). Fundamental principles of metaphysics of morals. New York: Dover.

Koestler, A. (1967). The ghost in the machine. London: Penguin.

Magna Charta $\quad$ Universitatum $\quad$ (1988). Retrieved from http://www.magna-charta.org/library/userfiles/file/mc_english.pdf

McHenry, H. D. (1997) Education as encounter: Buber's pragmatic ontology. Educational Theory, 47(3), 341-357.

Melville, H. (2009). The happy failure. New York: Harper Collins.

Montaigne, M. E. (1595/1958). The complete essays. Stanford: Stanford University Press.

Morin, E. (2003) $O$ método (vol. V): A humanidade da humanidade, a identidade humana. Mem Martins: Publicações Europa-América.

Neves, I. M. C. A. (2004). O homo educandus, ser agónico ou ser para a felicidade? - 0 contributo da educação para o desvelamento da intencionalidade própria do homem enquanto ser-em-situação-limite. In A. D. Carvalho (Org.), Problemáticas filosóficas da educação (pp. 65-130). Porto: Edições Afrontamento.

Orbe, F. B., Bondía, J. L, \& Sangrá, J.-C. (2006). Pensar la educación desde la experiencia. Revista Portuguesa de Pedagogia, 40(1), 233-259.

Pourtois, J. P. \& Desmet, H. (1997). L'éducation postmoderne. Paris: Presses Universitaires de France.

Rancière, J. (1987). Le maître ignorant: Cinq leçons sur l'émancipation intellectuelle. Paris: Fayard.

Reis, C. (2014). Educação e Cultura Mediática: Análise de implicações deseducativas. Lisboa: Âncora Editora. Sorbonne Declaration. Retrieved from http://www.wg.aegee.org/ewg/sorbonne.htm

Vansieleghem, N. \& Masschelein, J. (2012). Education as invitation to speak: On the teacher who does not speak. Journal of Philosophy of Education, 46(1), 85-99. 